\title{
Macrophage activation syndrome associated with systemic lupus erythematosus treated successfully with the combination of steroid pulse, immunoglobulin and tacrolimus
}

\author{
NATSUKI AOYAMA-MAEDA ${ }^{1}$, TARO HORINO ${ }^{1}$, OSAMU ICHII ${ }^{2}$, YOSHIO TERADA ${ }^{1}$ \\ ${ }^{1}$ Department of Endocrinology, Metabolism and Nephrology, Kochi Medical School, Kochi, \\ University, Kohasu, Oko-cho, Nankoku, Kochi 783-8505, Japan \\ ${ }^{2}$ Laboratory of Anatomy, Department of Biomedical Sciences, Graduate School of Veterinary Medicine, \\ Hokkaido University, Kita 18, Nishi 9, Kita-Ku, Sapporo, 060-0818, Japan
}

\begin{abstract}
Macrophage activation syndrome (MAS), a variant of secondary hemophagocyticlymphohistiocytosis, is a potentially life-threatening complication of inflammatory and autoimmune diseases. We present a case of MAS as a rare manifestation of systemic lupus erythematosus. Although initial treatment with corticosteroid, with or without cyclosporine A, is justified in patients with MAS, evidence regarding the effectiveness of this treatment protocol remains to be clarified. Our patient was successfully treated with a combination of intravenous immunoglobulin therapy and intravenous methyl predonisolone pulse therapy, which was followed by a course of oral prednisolone and oral tacrolimus. Based on our experience, we propose tacrolimus to provide a more useful adjuvant treatment to corticosteroid therapy than cyclosporine A.
\end{abstract}

Key words: hemophagocyticlymphohistiocytosis (HLH), intravenous immunoglobulin (IVIG), macrophage activation syndrome (MAS), systemic lupus erythematosus (SLE), tacrolimus (Tac).

\section{INTRODUCTION}

Hemophagocyticlymphohistiocytosis (HLH) is a potentially fatal condition resulting from excessive immune activation and it can occur either as a familial primary form or as a secondary response to a variety of events that disrupt immune homeostasis, such as infections, medications, neoplasms, and rheumatologic diseases [1]. Macrophage activation syndrome (MAS) is classified as a variant of HLH that is associated with autoimmune diseases.

\section{CASE REPORT}

A 36-year-old female presented with fever, cervical lymphadenopathy and polyarthralgia. Seven months prior to admission, her symptoms first presented as a facial erythema. Two months prior, she developed a high fever and subsequently cervical lymphadenopathy, polyarthralgia, and gingivitis, initially suspected a viral infection. Six weeks prior, she visited our hospital. Laboratory data revealed persistent elevation of ANA (1: 640),
dsDNA-Ab $(86.0 \mathrm{IU} / \mathrm{mL})$ and anti-RNP antibody (5.5 U/mL, < 5.0). She was diagnosed with systemic lupus erythematosus (SLE) based on the classification criteria for SLE [2], and oral prednisolone (PSL) $20 \mathrm{mg}$ daily was started, with a temporary resolution of her fever. One week prior, high fever and polyarthralgia recurred and progressed. She was admitted to our hospital.

Her symptoms at physical examination at admission were as follows: body temperature, $40.2^{\circ} \mathrm{C}$, and unremarkable respiratory and heart auscultation. A malar rash, oral ulcers, alopecia, lymphadenopathy, splenomegaly and polyarthralgia with tenderness were evident. Laboratory examination revealed elevated levels of C-reactive protein, lactate dehydrogenase and ferritin, thrombocytopenia, lymphocytepenia, liver dysfunction, and proteinuria (Table 1). All tests for possible infection (including hepatitis $B$ virus, hepatitis $C$ virus, EB virus, cytomegalovirus, human herpes virus and fungus) were negative. Hepatosplenomegaly was the only positive finding on computed tomography. Bone marrow aspiration was performed at one week post-admission, confirming hemophagocytosis (Figure 1). Based on the HLH diagnostic criteria, a diagnosis of HLH was 
made, with MAS secondary to HLH considered based on the clinical course (Figure 2). Initial treatment consisted of intravenous methyl prednisolone ( $1 \mathrm{~g} /$ day for 3 days), followed by oral PSL ( $1 \mathrm{mg} / \mathrm{kg}$ body weight, daily). Intravenous immunoglobulin (IVIG) therapy ( $20 \mathrm{mg} /$ day for 5 days) was added for persistent fever, transitioned, subsequently, to oral tacrolimus (Tac) $1 \mathrm{mg}$ daily. Symptoms resolved after 3 weeks of treatment, with laboratory findings within normal range. Six weeks after treatment initiation, oral PSL was tapered to $25 \mathrm{mg}$ daily and the patient was discharged without symptoms, with monthly follow-up. The patient remains symptom free at one year post-treatment.

Table 1

Laboratory data at first visit, admission and discharge

\begin{tabular}{|c|c|c|c|c|c|}
\hline & & Reference range & First visit & Admission & Discharge \\
\hline White blood cell count & $(/ \mu \mathrm{L})$ & $3,300-8,600$ & 1380 & 4,400 & 6,200 \\
\hline Lymphocyte & $(/ \mu \mathrm{L})$ & $990-2,990$ & 455 & 1,020 & 2,730 \\
\hline Hemoglobin & $(\mathrm{g} / \mathrm{dL})$ & $11.6-14.8$ & 12.0 & 12.3 & 12.0 \\
\hline Hematocrit & $(\%)$ & $35.1-44.4$ & 36.8 & 34.9 & 36.8 \\
\hline Platelet count & $\left(\times 10^{4} / \mu \mathrm{L}\right)$ & $15.8-34.8$ & 16.8 & 9.2 & 20.3 \\
\hline $\mathrm{Na}$ & $(\mathrm{mmol} / \mathrm{L})$ & $138-145$ & 140 & 130 & 141 \\
\hline $\mathrm{K}$ & $(\mathrm{mmol} / \mathrm{L})$ & $3.6-4.8$ & 4.1 & 3.8 & 3.1 \\
\hline $\mathrm{CL}$ & $(\mathrm{mmol} / \mathrm{L})$ & $101-108$ & 107 & 96 & 107 \\
\hline Creatinine & $(\mathrm{mg} / \mathrm{dL})$ & $0.46-0.79$ & 0.58 & 0.70 & 0.79 \\
\hline Blood uremic nitrogen & $(\mathrm{mg} / \mathrm{dL})$ & $8.0-20.0$ & 15 & 13 & 11 \\
\hline Uric acid & $(\mathrm{mg} / \mathrm{dL})$ & $2.6-5.5$ & 4.7 & 3.5 & \\
\hline Glucose & $(\mathrm{mg} / \mathrm{dL})$ & $73-109$ & 109 & 115 & 65 \\
\hline $\mathrm{HbA1c}$ & $(\%)$ & $4.6-6.2$ & 5.8 & & \\
\hline Total cholesterol & $(\mathrm{mg} / \mathrm{dL})$ & $142-248$ & 234 & 269 & 240 \\
\hline Triglyceride & $(\mathrm{mg} / \mathrm{dL})$ & $40-234$ & 126 & & \\
\hline ALT & $(\mathrm{U} / \mathrm{L})$ & $7.0-23.0$ & 47 & 29 & 10 \\
\hline AST & $(\mathrm{U} / \mathrm{L})$ & $13.0-30.0$ & 24 & 46 & 10 \\
\hline LDH & $(\mathrm{U} / \mathrm{L})$ & $124-222$ & 234 & 866 & 178 \\
\hline Total protein & $(\mathrm{g} / \mathrm{dL})$ & $6.6-8.1$ & 7.0 & 7.2 & 6.3 \\
\hline Albumin & $(\mathrm{g} / \mathrm{dL})$ & $4.1-5.1$ & 4.0 & 3.7 & 4 \\
\hline $\operatorname{IgG}$ & $(\mathrm{mg} / \mathrm{dL})$ & $861-1747$ & 1870 & & \\
\hline $\operatorname{IgA}$ & $(\mathrm{mg} / \mathrm{dL})$ & $93-393$ & 184 & & \\
\hline $\operatorname{IgM}$ & $(\mathrm{mg} / \mathrm{dL})$ & $50-269$ & 35 & & \\
\hline CRP & $(\mathrm{mg} / \mathrm{dL})$ & $<0.14$ & 0.01 & 9.34 & 0.01 \\
\hline Ferritin & $(\mathrm{ng} / \mathrm{mL})$ & $6.2-138$ & & 1212 & 127.2 \\
\hline Antinuclear antibody & & $<40 \mathrm{x}$ & $\begin{array}{c}640 x \\
\text { (speckled) }\end{array}$ & $\begin{array}{c}320 x \\
\text { (speckled) }\end{array}$ & \\
\hline Anti-dsDNA antibody & (IU/mL) & $<10.0$ & 86 & 13.3 & 5.0 \\
\hline Rheumatoid factor & $(\mathrm{IU} / \mathrm{mL})$ & $<15.0$ & $<3.0$ & & \\
\hline Anti-Sm antibody & $(\mathrm{U} / \mathrm{mL})$ & $<7.0$ & 101.0 & & \\
\hline Anti-RNP antibody & $(\mathrm{U} / \mathrm{mL})$ & $<5.0$ & 5.5 & & \\
\hline Anti-Scl70 antibody & $(\mathrm{U} / \mathrm{mL})$ & $<10.0$ & $<1.0$ & & \\
\hline Anti-SSA antibody & $(\mathrm{U} / \mathrm{mL})$ & $<7.0$ & $>240$ & & \\
\hline Anti-SSB antibody & $(\mathrm{U} / \mathrm{mL})$ & $<7.0$ & 2.4 & & \\
\hline Anti-ARS antibody & & $<25.0$ & 5.4 & & \\
\hline Anti-cardiolipin $\beta 2$ GPI antibody & $(\mathrm{U} / \mathrm{mL})$ & $<3.5$ & $<1.3$ & & \\
\hline Lupus anticoagulant & & $<1.3$ & 0.99 & & \\
\hline CH50 & $(\mathrm{U} / \mathrm{mL})$ & $25-48$ & 36.5 & $>60.0$ & 55.5 \\
\hline $\mathrm{C} 3$ & $(\mathrm{mg} / \mathrm{dL})$ & $73-138$ & 35.5 & 85.8 & 56.6 \\
\hline $\mathrm{C} 4$ & $(\mathrm{mg} / \mathrm{dL})$ & $11-31$ & 10 & 44.9 & 17.8 \\
\hline Immunocomplex (C1q) & $(\mu \mathrm{g} / \mathrm{dL})$ & $<3.0$ & 6.9 & 4.6 & \\
\hline Urinary protein excretion & $(\mathrm{mg} / \mathrm{gCr})$ & $0.0-300.0$ & 56.5 & 339.6 & 88.5 \\
\hline
\end{tabular}




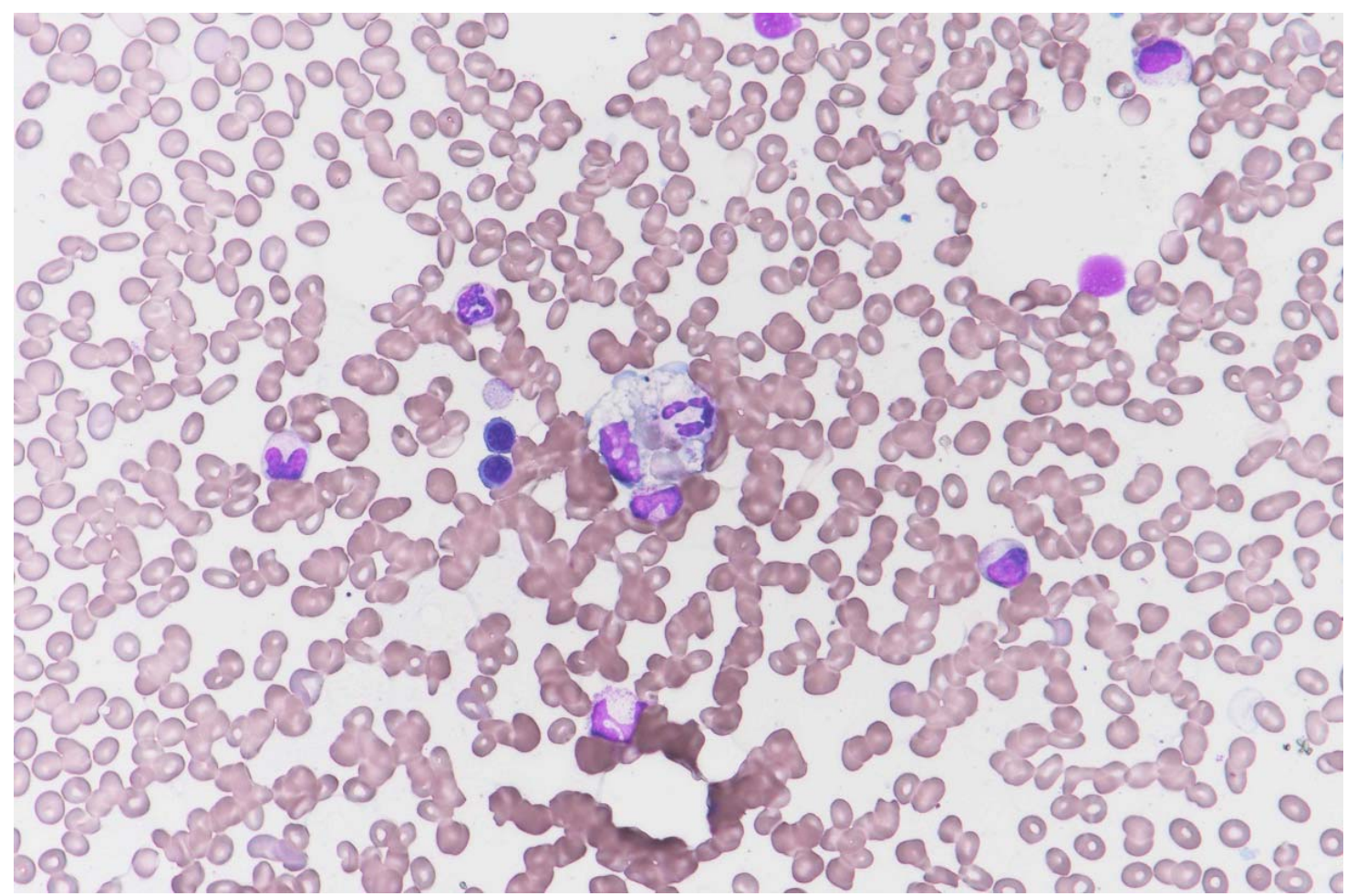

Figure 1. Histopathological examination of bone marrow aspirate showing hemophagocytic macrophage.

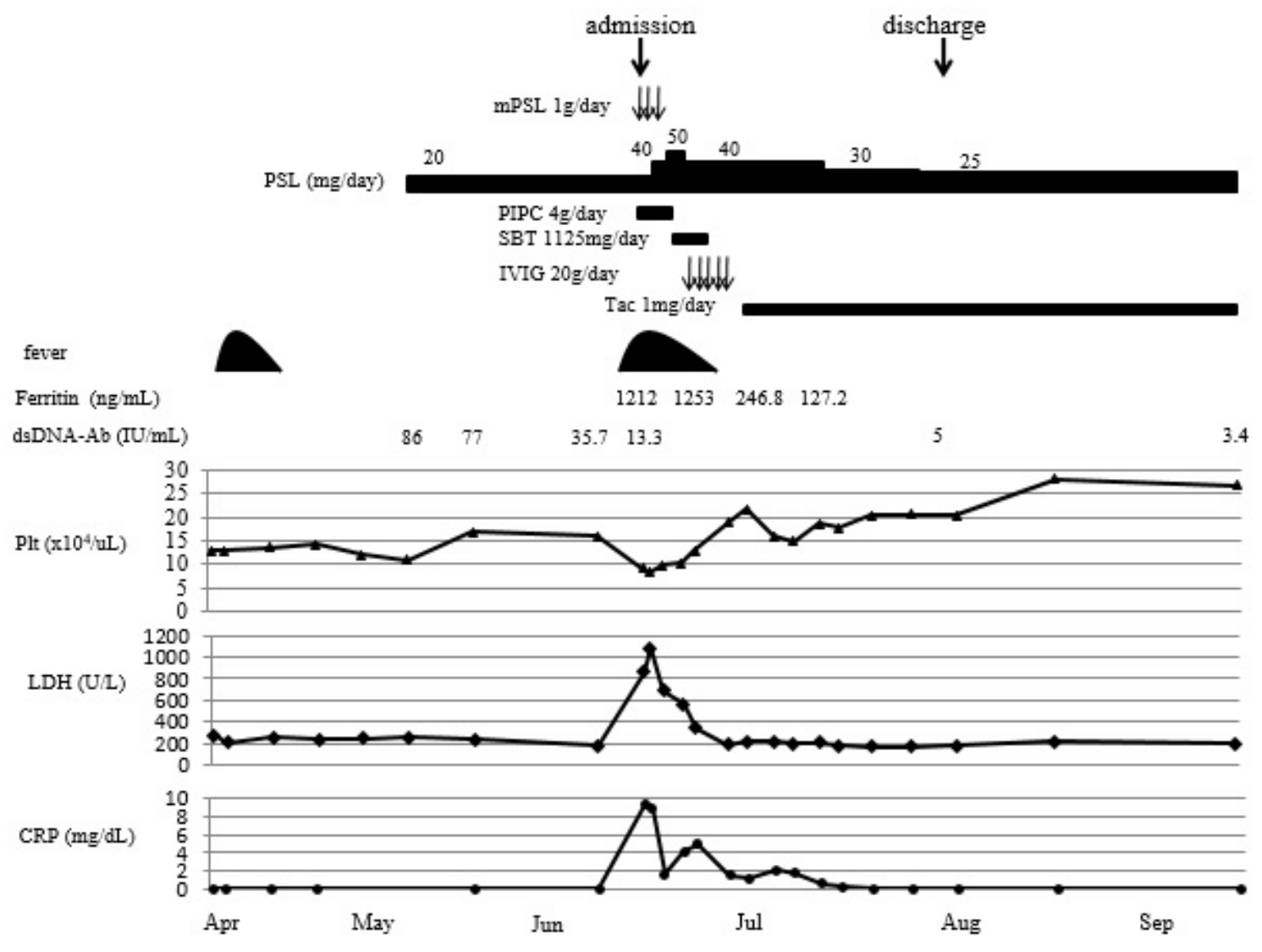

mPSL - methyl prednisolone, PSL - prednisolone, PIPC - piperacillin, SBT - sulbactam, IVIG - intravenous immunoglobulin, Tac - tacrolimus, dsDNA-Ab - anti-dsDNA antibody, Plt - platelet, LDH - lactate dehydrogenase, CRP - C-reactive protein.

Figure 2. Clinical course of the present case. 


\section{DISCUSSION}

MAS, secondary to HLH associated with autoinflammatory and autoimmune diseases, is thought to be caused by excessive activation and proliferation of $\mathrm{T}$ lymphocytes and macrophages. HLH occurs more frequently in children than in adults [3]. In patients with SLE, the incidence of MAS is estimated to be between $0.9 \%$ and $4.6 \%$ [4]. The true incidence, however, is likely to be underestimated, with cases being diagnosed as a flare-up or complication of SLE [5]. The diagnosis of MAS is challenging, with the clinical features of MAS-associated SLE and active SLE being very similar. Certain laboratory parameters inform the differentiation between these two diagnoses. Although severe leukopenia is commonly used as a marker of MAS, thrombocytopenia may provide a more responsive indicator of MAS than leukopenia or anaemia [1]. Hyperferritinemia is acknowledged to be the most appropriate parameter to discriminate between MAS-associated SLE and active SLE, with a sensitivity and specificity of almost $100 \%$ [5]. The patient in our case showed progressive thrombocytopenia and hyperferritinemia, with the diagnosis of SLE-associated MAS being made according to the HLH-2004 criteria [1].

In secondary HLH, and MAS in particular, an optimal treatment strategy has not been fully established. Current evidence supports the use of corticosteroid monotherapy, with or without cyclosporin A (CyA), with the resulting immunosuppression typically providing dramatic improvement of the disease status within days, with a sustained dose providing possible benefits in controlling the underlying autoimmune disease [3]. Use of CyA as the additional immunosuppressant for steroid-resistant MAS is typically recommended, with IVIG also being of benefit $[6,7]$. Other researchers have supported the use of Tac for the treatment of CyAresistant MAS [4]. The use of Tac has recently been supported by a meta-analysis providing evidence of the higher effectiveness of Tac in inducing complete remission of lupus nephritis than intravenous cyclophosphamide [8]. For our patient, we used IVIG therapy and oral tacrolimus with the goal of controlling the disease activity of SLE in addition to treating MAS.

\section{CONCLUSIONS}

MAS is a fatal complication of SLE, which is often difficult to distinguish from a flare-up of the disease status of SLE. For prompt diagnosis and early treatment intervention of MAS associated with SLE, it is essential to positively confirm the presence of MAS by bone marrow examination. Aggressive treatment is necessary in the early stages of the disease to gain control over the MAS status. Based on our experience, we propose IVIG therapy and oralTac to provide a better option to CyA to enhance treatment effectiveness.

Declaration of interest: The authors declare that there are no conflicts of interest.

Sindromul de activare macrofagică (MAS), variantă a limfohistiocitozei hemofagocitare, este o complicație amenințătoare de viață a bolilor autoimune şi inflamatorii. Prezentăm un caz de MAS ca manifestare rară în cadrul lupusului eritematos sistemic. Deşi tratamentul sugerat este inițial cu corticosteroid la care se poate adăuga ciclosporina $A$, eficiența acestei abordări terapeutice rămâne să fie clarificată. Pacientul nostru a fost tratat cu succes folosind imunoglobulină injectabilă, pulsterapie cu metilprednisolon urmat de o cură de prednison asociat cu tacrolimus oral. Bazat pe experiența noastră, propunem tacrolimusul ca tratament adjuvant terapiei cu glucocorticoizi în locul ciclosporinei $A$.

Correspondence to: Taro Horino, MD., PhD, Department of Endocrinology, Metabolism and Nephrology, Kochi Medical School, Kohasu, Oko-cho, Nankoku, Kochi 783-8505, Japan, Tel: +81-88-880-2343, Fax: +81-88-880-2344

E-mail: horinott@yahoo.co.jp

\section{REFERENCES}

1. HENTER JI., HORNE A., ARICÓ M., EGELER RM., FILIPOVICH AH., IMASHUKU S., et al. HLH-2004: Diagnostic and therapeutic guidelines for hemophagocyticlymphohistiocytosis. Pediatr Blood Cancer. 2007; 48(2):124-31.

2. TAN EM., COHEN AS., FRIES JF., MASI AT., MCSHANE DJ., ROTHFIELD NF., et al. The 1982 revised criteria for the classification of systemic lupus erythematosus. Arthritis Rheum. 1982; 25(11):1271-7. 
3. BODE SF., LEHMBERG K., MAUL-PAVICIC A., VRAETZ T., JANKA G., STADT UZ., et al. Recent advances in the diagnosis and treatment of hemophagocyticlymphohistiocytosis. Arthritis Res Ther. 2012; 14(3):213.

4. FUKAYA S., YASUDA S., HASHIMOTO T., OKU K., KATAOKA H., HORITA T., et al. Clinical features of haemophagocytic syndrome in patients with systemic autoimmune diseases: analysis of 30 cases. Rheumatology (Oxford). 2008; 47(11):1686-91.

5. EGÜES DUBUC CA., URIARTE ECENARRO M., MENESES VILLALBA C., ALDASORO CÁCERES V., HERNANDO RUBIO I., BELZUNEGUI OTANO J. Hemophagocytic syndrome as the initial manifestation of systemic lupus erythematosus. Reumatol Clin. 2014; 10(5):321-4.

6. KUMAKURA S., MURAKAWA Y. Clinical characteristics and treatment outcomes of autoimmune-associated hemophagocytic syndrome in adults. Arthritis Rheumatol. 2014; 66(8):2297-307.

7. JORDAN MB., ALLEN CE., WEITZMAN S., FILIPOVICH AH., MCCLAIN KL. How I treat hemophagocyticlym- phohistiocytosis. Blood. 2011; 118(15):4041-52.

8. HANNAH J., CASIAN A., D'CRUZ D. Tacrolimus use in lupus nephritis: A systematic review and meta-analysis. Autoimmun Rev. 2016; 15(1):93-101.

Received October 8, 2017 